\title{
Immigrant over- and under-education: the role of home country labour market experience
}

\author{
Matloob Piracha ${ }^{1 *}$, Massimiliano Tani ${ }^{2}$ and Florin Vadean ${ }^{3}$
}

\author{
* Correspondence: M.E.Piracha@ \\ kent.ac.uk \\ ${ }^{1}$ School of Economics, University of \\ Kent, Canterbury, Kent CT2 7NP, UK \\ and IZA, Bonn, Germany \\ Full list of author information is \\ available at the end of the article
}

\begin{abstract}
Literature on the immigrant labour market mismatch has not explored the signal provided by the quality of home country work experience, particularly that of education-occupation mismatch prior to migration. We show that type of work experience in the home country plays a significant role in explaining immigrant mismatch in the destination country's labour market. We use the Longitudinal Survey of Immigrants to Australia and find that having been over-educated in the last job held in the home country increases the likelihood of being over-educated in Australia by about 45 percent. Whereas having been under-educated in the home country has an even stronger impact, as it increases the probability to be similarly mismatched in Australia by 62 percent.
\end{abstract}

Keywords: Immigration, Education-occupation mismatch, Sample selection

JEL classification: $(34, J 24, J 61$

\section{Introduction}

Most of the existing literature in labour economics has argued that education is the key signal employers' use in determining the level of ability/productivity about those they are likely to employ. However, there is an argument that as the number of working years increases the strength of the education signal diminishes. For instance, Belman and Heywood (1997) has shown that "the returns to education signals will attenuate with workforce experience" as the skills used and/or developed in previous jobs become more important in determining the real productivity level of potential employees ${ }^{1}$. Skills gained through professional experience might be from jobs that do not match the individual's education level and, thus, might affect future job prospects in a diverging way. For example, having accumulated experience and skills below the education level may result in a lower probability of getting job offers that match the formal educational qualifications. Conversely, having advanced in a previous job to a position involving more knowledge and skills than the ones matching formal education may result in getting subsequent offers for jobs that require a relatively higher education level as well ${ }^{2}$.

Recent research on immigrants' over/under-education has typically focused only on the formal education qualifications of migrants and has compared the possible labour market mismatch of immigrants or ethnic minorities (i.e., second/third generation migrants) with natives. There is an almost universal consensus in the literature that immigrants are more often over-educated than their native counterparts and researchers forward different, and very plausible, arguments for this disparity. These range from imperfect international

(c) 2012 Piracha et al.; licensee Springer. This is an Open Access article distributed under the terms of the Creative Commons Attribution License (http://creativecommons.org/licenses/by/2.0), which permits unrestricted use, distribution, and reproduction in any medium, provided the original work is properly cited. 
transferability of human capital to discrimination in the labour market to, perhaps, a combination of language and country of origin effect (Chiswick and Miller 2009; Green et al. 2007).

However, the extant literature on the labour market mismatch of immigrants does not appear to have explored the possible impact of home country work experience signal, particularly the existence of education-occupation mismatch prior to migration. We attempt to fill this gap by including the role of home country over-/under-education as an additional determinant of immigrants' over-/undereducation in the host country's labour market. In other words, we want to explore the possible role of the home country's labour market signal on the incidence of mismatch in the host country. Our main hypothesis is that the imperfect transferability of human capital or discrimination in the host country does not exhaust the possible explanations for an immigrant's mismatch: we explicitly test for the possibility that the last job held prior to migration is a strong signal of a migrants' ability for a host country's employer. This analysis, therefore, will provide some evidence towards the role of the level of skills accumulated in previous jobs in the home country (i.e., below or above the education level) in explaining the incidence of subsequent mismatch in the host country, instead of, or in addition to those typically inferred to in the existing literature.

The significance of the human capital mismatch as an economic problem arises from its link with productivity and, in turn, its consequence on domestic wage inequality. Mismatched workers do not use efficiently their competences. This inefficiency is costly to the individuals involved, as they do not receive a salary commensurate with their abilities. It is also costly to society, as it does not make an efficient use of the finite stock of human capital available to it. In the case of over-education the cost is compounded by the fact that education is publicly subsidized; hence there is also wastage of public resources that could have been used otherwise. In the case of under-education, the cost is the lost opportunity, in terms of future potential output, of not giving enough formal education (or setting adequate incentives for doing so) to otherwise capable people. Within the over-I under-education literature, a line of research has consistently found that immigrants are significantly more over-/under-educated than comparable natives. The higher and persistent incidence of mismatch amongst immigrants is a potential problem for countries where foreigners form a substantial part of the labour force and where employment growth is mainly driven by immigration, as in Australia. Migration policy may in fact involuntarily contribute to destabilise, and not only expand, the domestic supply of skills by selecting people with a higher propensity to become mismatched. In such circumstances, understanding whether the source of such mismatch is attributable to institutional factors of the home or host countries is essential to identify which policy tools can be used to alleviate this problem. If this arises from an inefficient domestic labour market, then the host country may be able to improve the outcome of new immigrants through better coordination between immigration and labour market policies. This would however be void if the source of the mismatch occurs pre-migration. In that case, the host country may decide to revisit the criteria applied by an ineffective selection mechanism. 
In order to conduct the analysis, we exploit the Longitudinal Survey of Immigrants to Australia (LSIA), which contains detailed information about immigrants' education level, their occupation in Australia since arrival as well as their occupation in the home country in the 12 months prior to migration. Australia has a selective immigration policy, favouring immigrants who are young, highly educated and with prior work experience that is likely to be immediately transferable to the Australian labour market. Still, several studies have shown that immigrants are often employed below their education level and argued that immigrants' skills are not fully utilised in the Australian labour market (see for example Green et al. 2007). Our paper complements these studies in a specific way. Unlike the existing literature, our focus is not the comparison of immigrants' and natives' incidence of over-education, but the role of the signal from work experience in the home labour market in determining the labour mismatch in the host country.

Our results show that immigrants' education-occupation mismatch in the host country is, to a large extent, explained by their mismatch at home. The inclusion of dummies for the education-occupation mismatch in the home country along with covariates typically used in previous studies almost doubles the explanatory power of a probit model for over-education and almost quadruples that for under-education. Furthermore, after correcting for the sample selection bias into employment, we find that having been over-educated in the last job held in the home country increases the probability of being over-educated at five months after immigration by 45 percent. Similarly, having been under-educated in the home country increases the likelihood of undereducation in Australia by about 61 percent.

The rest of the paper is organised as follows. Section 2 discusses previous literature and outlines theoretical motivations while Section 3 presents the data. The empirical model used in the paper is presented in Section 4 and the discussion of results appears in Section 5. Section 6 concludes the paper.

\section{Previous literature and theoretical motivations}

We carry out our analysis within the framework of the existing over- and undereducation literature ${ }^{3}$. This literature typically proposes that there is a reference level of education that is required for a particular job, and when a worker is hired with an education level that diverges from the required level, a mismatch occurs ${ }^{4}$. This could be a level higher than needed for the job, in which case the worker is over-educated, or lower than the required level, in which case the worker is under-educated ${ }^{5}$.

These models have been extended to consider the mismatch of immigrants compared to those of natives ${ }^{6}$. All studies show that immigrants are much more likely to be mismatched (generally over-educated) than their native counterparts. There are several arguments put forward for that. For instance, Chiswick and Miller (2008); 2009, for analyses of Australia and the US, argue that the main reason for immigrant education mismatch is the less than perfect human capital transferability across borders, especially for those who migrate from less developed countries and/or those who have low host country language skills. Similarly, Green et al. (2007) use the LSIA to show that immigrants in Australia are much more likely to be over-educated than the natives and the difference is more pronounced for those coming from non-English speaking backgrounds. One other explanation put forward by Battu and Sloane (2004) is the possible discrimination against non-whites in the UK labour 
market, where they compare mismatch for ethnic minorities with those for white natives ${ }^{7}$. They argue that ethnic minorities possibly find it difficult to acquire jobs and therefore are likely to work in an occupation that is not fully commensurate with their qualification. Hence, on average more non-whites end up being over-educated. In other words, one can argue that to be able to send a stronger signal of ability, immigrants acquire more education, compared to natives, for the same job. Finally, some unobservable factors like motivation and innate abilities might be the reasons behind the results obtained in all studies analysing the labour market mismatch for immigrants (see Chiswick and Miller 2009).

Education-occupation mismatch is a dynamic process that is theorised to be affected by the individual's experience in the labour market. For example, the search-and-match theory hypothesises that mismatch originates from imperfect information about the labour market. Workers, thus, might take up jobs for which they are over-educated when they enter the labour market. However, they would continue to search for higher job levels and eventually move up the occupational ladder to positions that match or even exceed their formal qualifications (see Groot and Maassen van den Brink 2000; Hartog 2000). As argued by Chiswick and Miller (2009), this search and adjustment process can be particularly relevant for immigrants, especially for those from countries with labour markets that differ appreciably from those of the destination country. With residence length and the accumulation of information about the host country labour market, the incidence of over-education is expected to fall while the incidence of under-education could rise.

The human capital theory suggests that experience and skills acquired through on-the-job training could be often substitutes to formal schooling (see Sicherman 1991). Therefore, individuals may, at the start of their career, accept jobs below their education level with the intention of accumulating experience and skills for the benefit of an expected upward job mobility. Similar to the search and matching, the human capital theory predicts that with job experience over-education decreases, while under-education increases.

One of the few studies that considered the role of job experience accumulated in the home country in explaining the immigrants' education mismatch in the host country labour market is Chiswick and Miller (2009). They found that a greater amount of home country experience is associated with poorer job matches in the US and argued the imperfect international transferability of human capital as the main driving force for that outcome. The authors, however, implicitly assume no education mismatch in the immigrants' country of origin labour market. In other words, they suppose that the professional experience gained prior to immigration was in jobs requiring exactly the education level obtained from formal schooling.

We, however, diverge from the existing literature and argue that it is not only the education signal or some other observed characteristic, like race, that determines the incidence of mismatch, but the actual signal of "real" productivity from the previous "mismatched" work experience. We expect the level of professional experience at origin (i.e., below or above the education level) to significantly determine the immigrants' education mismatch incidence in the host country. For example, immigrants who have gained professional experience in the home country in jobs below their education level might be assessed by host country employers as having lower abilities and skills than those expected from their formal education, since the education signal attenuates with work experience. That might lead to employment below the education level in the host 
country as well. Therefore, if someone with tertiary education worked in the home country in a job that required only secondary education and is facing the same outcome in the host country, then it is less likely that the mismatch is due to imperfect transferability of skills and more likely due the lower on the jobs skills accumulated and/or some other unobservable factors (e.g., ability, motivation, ambition, and/or energy). If, however, the individual was properly matched in the home labour market but is over-educated in the host country, then perhaps the existing explanations of imperfect skill transferability and/or discrimination could be put forward for such an outcome.

Three broad approaches have been used in the literature to measure the incidence of under-/over-education. One approach, which is typically based on survey data, uses the workers' self assessment about the minimum education level needed for the job they perform or their understanding of the average education level for a particular job and whether they possess that or not (e.g., see Sicherman 1991; Dolton and Vignoles 2000). A second approach, developed by Verdugo and Verdugo (1989), uses the mean education level required across a range of occupations. Under this approach an individual is considered over- or under-educated if his education level is, respectively, one standard deviation above or below the mean education level required for that particular job. A third way to analyse the level of over-/under-education is the "objective" measure based on methods used by different countries/labour organizations to assess the average required education for a particular job (e.g., Rumberger 1987 and Green et al. 2007). We adopt the last approach in this paper.

We use the Australian Standard Classification of Occupation (ASCO) codes to divide the employed immigrants in eight occupational groups: Managers and Administrators; Professionals; Para-Professionals; Tradespersons; Clerks; Salespersons and Personal Service Workers; Plant and Machine Operators and Drivers; and Labourers and Related Workers. For each occupation group Australia's Department of Immigration and Citizenship (DIAC) associates a corresponding required level of education ${ }^{8}$. Those who have surplus education to that required by DIAC are considered over-educated, while those who have less are considered under-educated. The related education levels for each categories and further explanation is provided in section 3 below.

\section{Data}

The Longitudinal Survey of Immigrants to Australia (LSIA) is a panel survey of three cohorts of immigrants to Australia: LSIA 1 covers migrants who arrived in Australia between September 1993 and August 1995 and contains three waves, with interviews conducted at 5, 17 and 41 months after arrival; LSIA 2 consists of two waves with interviews conducted at 5 and 17 months after arrival of immigrants who arrived between September 1999 and August 2000; while LSIA 3 has only one wave and samples immigrants who arrived in Australia (or were granted their visa onshore) between December 2004 and March 2005. The substantially smaller number of questions in LSIA 3 relative to LSIA 1 and 2 makes it difficult to carry out the analysis over the three cohorts. Therefore, this paper uses only data from LSIA 1 and LSIA $2^{9}$.

The LSIA was commissioned in the early 1990s to fulfil the need to have better information on the settlement of new migrants than those available through censuses. It is 
based on a representative sample of 5 percent of migrants/refugees from successive cohorts of migrants. LSIA 1 and LSIA 2 contain more than 300 questions about the settlement process and conditions experienced pre-emigration in the home country and after relocating to Australia. The LSIA is carried out separately on primary applicants and migrating-unit spouses ${ }^{10}$. There are 5,192 primary applicants and 1,838 spouses in Cohort 1, while 3,124 primary applicants and 1,094 spouses were interviewed as part of Cohort 2 .

Australian immigration policy became more restrictive for all migrants who entered after 1995 (i.e., Cohort 2 in our paper), except for those in the humanitarian stream ${ }^{11}$. The policy restrictions, intended to favour migrants with skills immediately usable in the labour market, included higher language proficiency requirements as well as higher weight attached to other employability factors namely occupational skills, education and age. As a result, migrants in Cohort 2 have a higher average level of education, higher participation rates (see Cobb-Clark 2003; Chiswick and Miller 2004), and lower durations to access their first job (Thapa and Gorgens 2006) than those in Cohort 1, though they appear to have lower quality initial jobs (Junankar and Mahuteau 2005).

Among the several questions asked in both LSIA 1 and LSIA 2, we capture the education-occupation mismatch by comparing the level of education acquired by the migrant with the level of education required to perform the migrant's job as defined by DIAC. This definition assigns the (formal) educational requirement for managers, administrators and professionals - who are classified in the ASCO occupational categories 1-3 as "bachelor or higher". For associate professionals, tradespersons, clerks, salespersons and personal service workers, and plant and machine operators and drivers (ASCO 4-7) the educational requirement is a "diploma or vocational degree". For labourers and related workers (ASCO $8-9)$ it is "secondary or less" education.

We consider as over-educated all those respondents who have a level of education that is above what is required by DIAC to perform the tasks of the occupation held. This includes individuals who have a tertiary education but have an occupation that requires only secondary or vocational education, and individuals who have vocational education but have an occupation that requires secondary education. Conversely, the under-educated include individuals who have an education level lower than the one required for their job.

We consider ASCO for the assessment of the education-occupation mismatch in the former home country as well. Despite the fact that the countries of origin may have different education requirements for specific jobs compared to Australia, we believe that for the objective of this analysis the Australian employer perspective is of primary importance. An Australian employer would certainly be less likely to have extensive knowledge about occupation classification standards of other countries. Therefore, he would most likely assess the former home country labour market experience of immigrants according to the Australian standards. Moreover, we use very broad occupation and education groups (i.e., three groups each) generalisation that certainly compensates for most of the differences in education requirements between countries.

Due to limited number of observations in certain categories (e.g., immigrants that were over-educated in the home country but are under-educated in Australia), we need to pool Cohort 1 and 2 in our empirical analysis discussed in section 5. This then limits us to use only the first two waves of Cohort 1 as Cohort 2 does not have a third wave. 
Furthermore, our focus on males reflects the limited number of female immigrants that appear as participating in the labour market in the LSIA.

From Table 1, it can be seen that male immigrants are typically in their mid-30's, have a small family, with one or two dependent children. The majority is highly educated, with approximately two thirds holding a diploma/certificate or higher educational qualification. The main countries of former residence are English speaking OECD countries (i.e., Canada, Ireland, the United Kingdom, and the United States; above 20 percent for both cohorts) and South, East, South East Asia and Oceania (between 36 and 41 percent).

Table 2 presents the education mismatch transitions between the occupational status in the job held in the home country during the last 12 months before migration and the occupational status at five months after arrival in Australia. Perhaps unsurprisingly, many of those who had a job in the home country prior to migration were unemployed in the first months after migrating to Australia. On average 31 percent of immigrants were unemployed at five months after arrival, with the highest incidence of unemployment among those who were unemployed or not in the labour force at home (about 47 percent). The overall incidence of unemployment drops at 17 months after arrival to about 20 percent, and is even less for those who held a job matched with their formal educational qualifications at home (about 15 percent; see Table 3). There is also substantial persistence in the educational mismatch between home and host countries among those who were employed both prior and after migration: 41 percent of the over-educated at home were over-educated in their job in Australia at five months after arrival; the rate increases to about 51 percent at 17 months after arrival, as part of those who were initially unemployed enter into employment. This path dependency can be observed with respect to under-education as well: of those who were undereducated at home, about 46 percent were under-educated at five months and 47 percent at 17 months after immigration to Australia.

Table 4 illustrates that the educational mismatch persistence remains during the period analysed (17 months after arrival). Over 61 percent of those over-educated in the initial jobs at arrival continued to work in positions that required a lower level of formal education even after 17 months of residence, and about 79 percent of those who were initially under-educated remained in jobs that required a higher level of formal education.

\section{Empirical methods}

The primary concern of this paper is to model the determinants of a mismatch between the actual education and the one formally required for the occupation (i.e., overeducation and under-education respectively) among immigrants in the Australian labour market. Given the fact that the mismatch is observed only for the employed individuals, an exclusive focus on those immigrants who have an occupation may overlook the fact that they might constitute a non-randomly selected sub-sample (see, for instance, Dolton and Vignoles 2000). Bauer (2002) and Cutillo and Di Pietro (2006) argue that the presence of possible heterogeneity of ability in the population could have a significant impact on the labour market outcome and consequently the extent of over- and under-education in the employed subsample. Given Australia's different visa regimes which range from high skilled immigrants to refugees and those who entered 
Table 1 Descriptive Statistics - male immigrants aged 21 to 64

\begin{tabular}{|c|c|c|c|c|}
\hline & \multicolumn{2}{|c|}{ Cohort 1} & \multicolumn{2}{|c|}{ Cohort 2} \\
\hline & Wave 1 & Wave 2 & Wave 1 & Wave 2 \\
\hline Age & 34.25 & 35.11 & 35.27 & 36.42 \\
\hline No. of adults in household & 2.81 & 2.43 & 2.60 & 2.36 \\
\hline No. of children in household & 1.55 & 1.48 & 1.56 & 1.49 \\
\hline Education: Postgraduate & 0.22 & 0.23 & 0.28 & 0.27 \\
\hline Education: Bachelor & 0.23 & 0.22 & 0.25 & 0.21 \\
\hline Education: Diploma/Certificate & 0.21 & 0.21 & 0.21 & 0.21 \\
\hline Education: Completed secondary or trade & 0.23 & 0.23 & 0.21 & 0.24 \\
\hline Education: Some secondary or less & 0.12 & 0.11 & 0.06 & 0.07 \\
\hline FHC: English Speaking OECD & 0.20 & 0.19 & 0.24 & 0.22 \\
\hline FHC: Non-English Speaking OECD & 0.13 & 0.12 & 0.15 & 0.13 \\
\hline FHC: South, East, South East Asia \& Oceania & 0.36 & 0.35 & 0.38 & 0.40 \\
\hline FHC: Sub-Saharan Africa & 0.08 & 0.08 & 0.09 & 0.09 \\
\hline FHC: Other & 0.23 & 0.26 & 0.14 & 0.15 \\
\hline Qualification assessed & 0.33 & 0.39 & 0.30 & 0.30 \\
\hline Self-employment & 0.07 & 0.10 & 0.11 & 0.17 \\
\hline Interview in English & 0.73 & 0.79 & 0.84 & 0.87 \\
\hline Visited Australia before immigration & 0.48 & 0.45 & 0.65 & 0.62 \\
\hline Visa type: Preferential Family/Family Stream & 0.26 & 0.25 & 0.32 & 0.33 \\
\hline Visa type: Concessional Family/Skilled-Austr. Link & 0.21 & 0.21 & 0.15 & 0.15 \\
\hline Visa type: Business Skills \& Empl. Nom. Scheme & 0.17 & 0.17 & 0.21 & 0.22 \\
\hline Visa type: Independent & 0.23 & 0.23 & 0.24 & 0.20 \\
\hline Visa type: Humanitarian & 0.13 & 0.13 & 0.08 & 0.09 \\
\hline HH owns car & 0.71 & 0.85 & 0.67 & 0.83 \\
\hline Occup in AU: Managers \& Administrators & 0.13 & 0.13 & 0.15 & 0.15 \\
\hline Occup in AU: Professionals & 0.31 & 0.28 & 0.37 & 0.32 \\
\hline Occup in AU: Para-Professionals & 0.03 & 0.04 & 0.10 & 0.13 \\
\hline Occup in AU: Tradespersons & 0.20 & 0.21 & 0.17 & 0.16 \\
\hline Occup in AU: Clerks & 0.02 & 0.02 & 0.01 & 0.02 \\
\hline Occup in AU: Salespersons \& Pers. Serv. Workers & 0.07 & 0.07 & 0.10 & 0.09 \\
\hline Occup in AU: Plant \& Machine Operators \& Drivers & 0.06 & 0.09 & 0.06 & 0.08 \\
\hline Occup in AU: Labourers \& Related Workers & 0.17 & 0.17 & 0.04 & 0.05 \\
\hline Educ. mismatch AU: Unemployed & 0.36 & 0.20 & 0.21 & 0.11 \\
\hline Educ. mismatch AU: Over-educated & 0.12 & 0.16 & 0.13 & 0.16 \\
\hline Educ. mismatch AU: Correctly matched & 0.39 & 0.50 & 0.51 & 0.52 \\
\hline Educ. mismatch AU: Under-educated & 0.13 & 0.14 & 0.15 & 0.21 \\
\hline Educ. mismatch FHC: Not working & 0.11 & 0.11 & 0.10 & 0.12 \\
\hline Educ. mismatch FHC: Over-educated & 0.08 & 0.08 & 0.10 & 0.08 \\
\hline Educ. mismatch FHC: Correctly matched & 0.56 & 0.57 & 0.59 & 0.57 \\
\hline Educ. mismatch FHC: Under-educated & 0.24 & 0.25 & 0.21 & 0.23 \\
\hline Region of residence: New South Wales & 0.41 & 0.43 & 0.39 & 0.36 \\
\hline Region of residence: Victoria & 0.26 & 0.25 & 0.24 & 0.24 \\
\hline Region of residence: Queensland & 0.11 & 0.11 & 0.09 & 0.11 \\
\hline Region of residence: South Australia & 0.05 & 0.05 & 0.05 & 0.05 \\
\hline
\end{tabular}


Table 1 Descriptive Statistics - male immigrants aged 21 to 64 (Continued)

\begin{tabular}{lllll}
\hline Region of residence: Western Australia & 0.12 & 0.12 & 0.14 & 0.15 \\
Region of residence: Tasmania & 0.01 & 0.01 & 0.02 & 0.02 \\
Region of residence: Northern Territory & 0.01 & 0.01 & 0.01 & 0.01 \\
Region of residence: A.C.T. & 0.02 & 0.02 & 0.05 & 0.05 \\
No. of observations & 2,127 & 2,011 & 921 & 907 \\
\hline
\end{tabular}

Note: FHC stands for "Formal Home Country".

on family visa, the immigrant sample is likely to be quite heterogeneous in ability and home country experiences.

Only about 68.6 percent of male immigrants in the potential labour force had employment at five months after immigration and 80.5 percent one year later. Taking into consideration the fact that the two possible types of mismatch (i.e., over-education and under-education) are observed only if the individual is employed, we apply a binomial probit model in order to correct for eventual sample selection bias. This approach follows Green et al. (2007), who use the same database and identification variables.

The occurrence of the mismatch $j$ - which stands for either over- or undereducation - may be illustrated by the following two linear latent dependent variable equations:

$$
y_{1 j}^{*}=x_{i}^{\prime} \beta+u_{i}
$$

where $y_{1 i j}=1$ if the individual has attained the respective mismatch $\left(y_{1 i j}^{*}>0\right)$ and $y_{1 i j}=0$ if not $\left(y_{1 i j}^{*} \leq 0\right)$

$$
y_{2 i}^{*}=z_{i}^{\prime} \gamma+v_{i}
$$

where $y_{2 i}=1$ if the individual is employed $\left(y_{2 i}^{*}>0\right)$ and $y_{2 i}=0$ if not $\left(y_{2 i}^{*} \leq 0\right)$.

The dichotomous variable $y_{1 i j}$ is only observed if $y_{2 i}=1$. The model was first presented by Van De Ven and Van Praag (1981) to examine deductibles in private health insurance in the Netherlands. Variants of the model have then been used, for example, by Boyes et al. (1989) for analysing the default on loans while taking into account whether an application for a loan was accepted or not and Litchfield and Reilly (2009)

Table 2 Transition matrix of education mismatch between home country and $\mathbf{5}$ months after arrival in Australia (Cohort 1\&2)

\begin{tabular}{lccccc}
\hline \multirow{2}{*}{$\begin{array}{c}\text { Education mismatch } \\
\text { in home country }\end{array}$} & \multicolumn{5}{c}{ Education mismatch in Australia - 5 months after arrival } \\
\cline { 2 - 6 } & Unemployed & Over-educated & Correctly matched & Under-educated & Total \\
\hline Not working & 46.81 & 12.77 & 28.37 & 12.06 & 100 \\
Over-educated & 39.11 & 41.13 & 19.35 & 0.40 & 100 \\
Correctly matched & 26.50 & 11.98 & 59.21 & 2.31 & 100 \\
Under-educated & 33.96 & 2.80 & 16.98 & 46.26 & 100 \\
Total & 31.35 & 12.53 & 42.99 & 13.13 & 100 \\
\hline
\end{tabular}

Note: The "Not working" subgroup in the case of "education-occupation mismatch in the home country" includes besides unemployed also individuals that were not in the labour force, since some of them are employed or are looking for a job once in Australia. 
Table 3 Transition matrix of education mismatch between home country and 17 months after arrival in Australia (Cohort 1\&2)

\begin{tabular}{lccccc}
\hline \multirow{2}{*}{$\begin{array}{c}\text { Education mismatch } \\
\text { in home country }\end{array}$} & \multicolumn{5}{c}{ Education mismatch in Australia - 17 months after arrival } \\
\cline { 2 - 6 } & Unemployed & Over-educated & Correctly matched & Under-educated & Total \\
\hline Not working & 37.45 & 14.74 & 31.87 & 15.94 & 100 \\
Over-educated & 20.62 & 50.52 & 28.35 & 0.52 & 100 \\
Correctly matched & 14.83 & 18.15 & 63.47 & 3.54 & 100 \\
Under-educated & 22.30 & 3.60 & 26.76 & 47.34 & 100 \\
Total & 19.51 & 16.87 & 48.30 & 15.32 & 100 \\
\hline
\end{tabular}

Note: The "Not working" subgroup in the case of "education-occupation mismatch in the home country" includes besides unemployed also individuals that were not in the labour force, since some of them are employed or are looking for a job once in Australia.

to investigate whether an individual has attempted to migrate conditional on having considered migrating.

Equation (2) is fully observed and can be estimated separately. However, separate estimation of mismatch attainment (Eqn. 1) may be subject to selection bias given the potential for correlation between the two error terms $u_{i}$ and $v_{\mathrm{i}}$. The model can be estimated stepwise (i.e., the inverse Mill's ratio of the selection equation is introduced as a covariate in the outcome probit equation) or by maximum likelihood. Relative to the maximum likelihood approach, the two-step method is often perceived to give inconsistent results, in particular in the case when there is strong multicollinearity between covariates in the outcome and the selection equations (e.g., when using a joint set of covariates; see Lahiri and Song 2000).

For each type of mismatch, the log-likelihood function to be evaluated is:

$$
\begin{aligned}
\ln L_{j}(\beta, \gamma, \rho)= & \sum_{i}^{N}\left\{y_{1 i j} y_{2 i} \ln \Phi_{2}\left(x_{i}^{\prime} \beta, z_{i}^{\prime} \gamma ; \rho\right)\right. \\
& +\left(1-y_{1 i j}\right) y_{2 i} \ln \Phi_{2}\left(-x_{i}^{\prime} \beta, z_{i}^{\prime} y ;-\rho\right) \\
& \left.+\left(1-y_{2 i}\right) \ln \left(1-\Phi\left(z_{i}^{\prime} y\right)\right)\right\}
\end{aligned}
$$

Table 4 Transition matrix of education mismatch between 5 and 17 months after arrival in Australia (Cohort 1\&2)

\begin{tabular}{lccccc}
\hline $\begin{array}{c}\text { Education mismatch } \\
\text { in Australia - 5 months } \\
\text { after arrival }\end{array}$ & \multicolumn{5}{c}{ Education mismatch in Australia - 17 months after arrival } \\
\cline { 2 - 6 } & Unemployed & Over-educated & Correctly matched & Under-educated & Total \\
\hline Not working & 39.33 & 17.52 & 30.57 & 12.57 & 100 \\
Over-educated & 6.11 & 61.45 & 30.15 & 2.29 & 100 \\
Correctly matched & 3.02 & 6.52 & 86.11 & 4.35 & 100 \\
Under-educated & 4.53 & 1.23 & 15.64 & 78.60 & 100 \\
Total & 19.51 & 16.87 & 48.30 & 15.32 & 100 \\
\hline
\end{tabular}

Note: The "Not working" subgroup in the case of "education-occupation mismatch in Australia at 5 months after arrival" includes besides unemployed also individuals that are were initially not in the labour force, since some of them are employed or are looking for a job one year later. 
where $\rho$ denotes the correlation coefficient between the error terms $u_{i}$ and $v_{i} ; \Phi_{2}(\cdot)$ denotes the bivariate standard normal cumulative distribution function; and $\Phi(\cdot)$ the univariate standard normal cumulative distribution function. The parameters of Eqns. (1) and (2) are estimated jointly by maximizing the log-likelihood function (3) with respect to the coefficient vectors $\beta$ and $\gamma$ and the correlation coefficient $\rho$. The estimate of $\rho$ provides a test for selectivity bias. If $\rho$ is significantly different from zero, the coefficients of Eqn. (1) would have been biased if estimated separately by binomial probit.

The identification of such selectivity models is of crucial importance. Identification is achieved by the inclusion of variables in Eqn. (2) that are excluded from Eqn. (1). Poor identification restrictions can lead to erroneous conclusions regarding the presence of selectivity effects. In the context of our application it would be of some interest to establish if, having controlled for a set of observable characteristics, the employed respondents possessed unobservable characteristics (e.g., motivation, cognitive abilities, etc.) that were in some way different from the whole sample. A statistically significant $\rho$ value may provide an insight into this particular issue. However, confidence in the reliability of such a result depends crucially on appropriate identification. There is a set of variables that appear in $z_{i}^{\prime}$ but not in $x_{i}^{\prime}$ as well as a set that is common to both vectors. In addition, there are variables that appear in $x_{i}^{\prime}$ but not in $z_{i}^{\prime}$, though these are not crucial for identification.

Following the empirical study of Green et al. (2007) the covariates chosen to identify the model (i.e., variables appear in $z_{i}^{\prime}$ but not $x_{i}^{\prime}$ ) are: car ownership, the household structure, a control for whether the immigrant visited Australia prior to immigration, a variable indicating whether the immigrant had own funds at the time of arrival and English proficiency.There are both theoretical and empirical reasons for these identifying restrictions. As shown in previous studies, owning a motor vehicle might increase the area where the individual can take up a job and, thus, the employment opportunities (see Raphael and Stoll, 2000; Green et al., 2007). Theoretically, however, there is no relation between car ownership and labour market experience and/or abilities. Education-occupation mismatch shall, therefore, not be dependent on car ownership.

The family structure may affect the probability of employment as well. For instance, the presence of other adults in the household might ease the pressure of taking up employment. On the other side, immigrant men with dependent children (i.e., at or below school age) present might be under greater pressure of taking up employment (see Lundberg and Rose, 2002). Moreover, Green et al. (2007) argue that immigrants who have visited Australia prior to settlement are likely to have better knowledge of the Australian labour market or have already established contacts with Australian employers. Hence, we control for both the effect of the number of adults, the number of dependent children in the household and the knowledge of the Australian labour market through prior visits on the probability of being in employment. None of these variables should be correlated with labour market experience and/or abilities and, hence, education-occupation mismatch.

Two more identification instruments used by Green et al. (2007) are a control for having funds at the time of arrival and English language proficiency. They suggest that immigrants who face liquidity constraints might also be more likely to be under pressure to take up employment and the proficiency level of the host country language may have a positive effect on the probability of employment. Nevertheless, both savings and language proficiency could be correlated to innate abilities and, thus to education- 
occupation mismatch. Therefore, we test for the validity of these instruments as suggested by Murray (2006): the selection instruments are introduced as covariates in both the selection and the outcome equations (i.e., in both $z_{i}^{\prime}$ and $x_{i}^{\prime}$ ); the rejection of the null hypothesis that these additional instruments all have zero coefficients in the outcome equation (Eqn. 1) would support their validity as instruments.

The test results show that for both cases the null hypothesis cannot be rejected and, therefore, the instruments are valid. However, contrarily to Green et al. (2007), we find that the dummy controlling for having funds at time of immigration is not significant in the selection equation and is, hence, a weak instrument. For simplicity and given the fact that we have five valid instruments, we will not include the control for having funds at arrival in the estimation.

Our primary covariates of interest are a set of dummy variables included only in the outcome equation and control for the type of mismatch between the educational level and the occupational attainment in the last job held in the former home country in the 12 months prior to immigration (i.e., over-educated, correct match, under-educated). Having not worked during the last 12 months prior to immigration is the reference group for the dummy set. Moreover, immigrants enter Australia with formal experience gained from a large variety of labour markets. In order to capture differences in "quality" of previous labour market experience, we include in a second specification of our empirical model controls for the former home country as well.

\section{Empirical results}

We start the analysis by assessing the importance of our variables of interest in improving the explanatory power of the empirical model. In this first step - making abstraction of the eventual sample selection bias - we compare the adjusted R-squared from a binomial probit estimation of Eqn. (1), with and without including the set of dummies for the type of mismatch between the education level and the occupational attainment in the last job held in the home country twelve months prior to immigration.

The results show that the education-occupation mismatch incidence in the home country adds significantly to the explanation of the variation in the immigrants' mismatch in Australia (see Figure 1). Compared to a model that has as covariates only socio-economic controls used in pervious studies (i.e., age, age squared, a dummy for having the qualification assessed in Australia, dummies for the former region of residence, dummies for the entry visa type, a dummy for school age children present, a dummy for having financial funds at time of entry, and regional dummies), the inclusion of covariates controlling for the mismatch in the home country almost doubles the explanatory power of the probit estimation for over-education at five months after arrival in Australia (i.e., adjusted R-square increases from 0.13 to 0.27 ) and almost quadruples the explanatory power of probit estimation for under-education at five months after arrival (i.e., adjusted R-squared increase from 0.14 to 0.50 percent).

The estimation results of the probit models with sample selection, for over- and undereducation at five and 17 months after arrival, respectively, are presented in Tables 5 and 6 . Both the selection into employment and the education mismatch equations include controls for heterogeneity in the labour market and economic conditions in different Australian states ${ }^{12}$. 


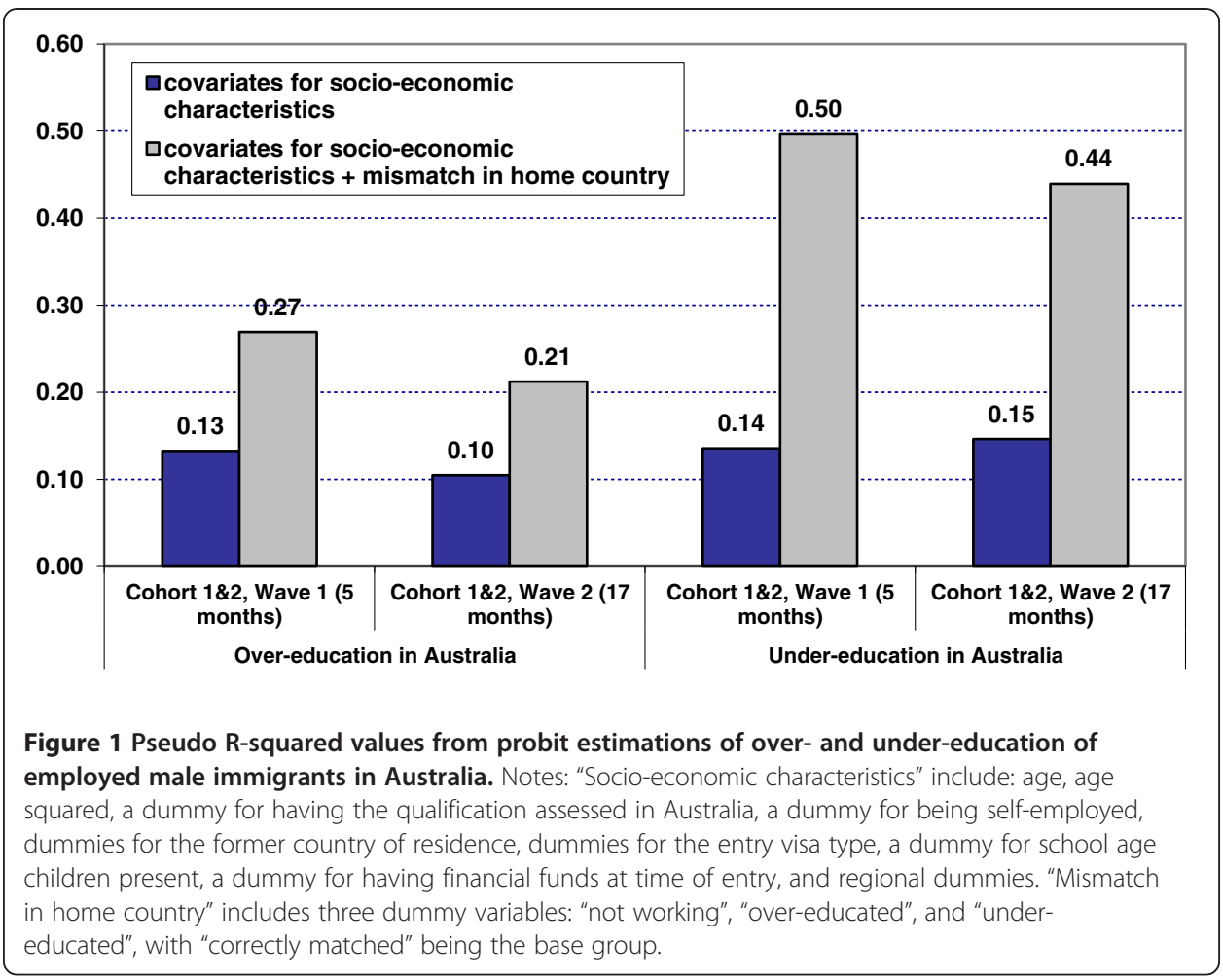

Similar to findings in previous studies, the selection into employment is found to be positively related to host country language proficiency, knowledge of the Australian labour market over previous country visits, having obtained the entry visa after screening for labour market and/or business skills, having a car, and having dependent children in the household (see Green et al., 2007). The probability of being employed is negatively affected by having entered Australia on a humanitarian visa, which could be evidence of having relatively lower skill level, and the presence of other adults in the household that might contribute to the household income. Moreover, at five months after arrival, immigrants in Cohort 2 are about 14 percent more likely to be in employment compared to immigrants in Cohort 1, probably due to the stricter access to unemployment benefits introduced in 1996.

The error term of the selection equation is positively correlated with the error term of the over-education equation, indicating that there are unobservable factors that affect similarly the likelihood of both employment and over-education. One explanation could be that relatively "low-level" jobs are accepted to avoid the stigma of being unemployed, or perhaps there are other financial/family pressures to accept "any" job at the start of the immigration process, with the aim to improve in terms of occupational mobility, as opportunities improve with time spent in Australia.

Australian employers seem to take into consideration signals about the immigrants' labour market abilities from the education mismatch incidence in the last job in the home country. At five months after immigration and conditional on being employed, immigrants who have been over-educated in the job held in the home country 12 months prior to immigration have about 45 to 48 percent higher likelihood to be over-educated in Australia. Similarly, having been under-educated in the last job in the home country increases the 
Table 5 Probit with sample selection estimates of over- and under-education (marginal effects) - Cohort 1\&2, Wave 1 (5 months after arrival)

\begin{tabular}{|c|c|c|c|c|}
\hline & (1) & $(2)$ & (3) & (4) \\
\hline & \multicolumn{2}{|c|}{ Over-education } & \multicolumn{2}{|c|}{ Under-education } \\
\hline \multirow[t]{2}{*}{ Age } & 0.021 & 0.006 & 0.001 & -0.001 \\
\hline & {$[0.008]$} & {$[0.009]$} & {$[0.006]$} & {$[0.006]$} \\
\hline \multirow[t]{2}{*}{ Age squared $\times 100$} & -0.009 & -0.011 & 0.001 & 0.001 \\
\hline & {$[0.011]$} & {$[0.012]$} & {$[0.008]$} & {$[0.008]$} \\
\hline \multirow[t]{2}{*}{ Qualification assessed } & 0.022 & 0.025 & -0.069 & -0.070 \\
\hline & {$[0.019]$} & {$[0.020]$} & {$[0.016]^{* * *}$} & {$[0.015]^{* * *}$} \\
\hline \multirow[t]{2}{*}{ Self-Employed } & -0.070 & -0.077 & 0.144 & 0.155 \\
\hline & {$[0.021]^{* * *}$} & {$[0.023]^{* * *}$} & {$[0.035]^{* * *}$} & {$[0.036]^{* * *}$} \\
\hline \multirow[t]{2}{*}{ FHC: Non-English Speaking OECD } & & 0.019 & & -0.025 \\
\hline & & {$[0.032]$} & & {$[0.017]$} \\
\hline \multirow[t]{2}{*}{ FHC: South, East, South East Asia and Oceania } & & 0.133 & & -0.055 \\
\hline & & {$[0.029]^{* * *}$} & & {$[0.015]^{* * *}$} \\
\hline \multirow[t]{2}{*}{ FHC: Sub-Saharan Africa } & & 0.092 & & -0.003 \\
\hline & & {$[0.047]^{*}$} & & {$[0.024]$} \\
\hline \multirow[t]{2}{*}{ FHC: Other } & & 0.135 & & -0.027 \\
\hline & & {$[0.041]^{* * *}$} & & {$[0.020]$} \\
\hline \multirow[t]{2}{*}{ Visa type: Concessional Family/Skilled-Austr. Link } & 0.012 & -0.008 & -0.002 & 0.005 \\
\hline & {$[0.022]$} & {$[0.024]$} & {$[0.022]$} & {$[0.022]$} \\
\hline \multirow[t]{2}{*}{ Visa type: Business Skills \& Empl. Nomination Scheme } & -0.163 & -0.171 & 0.009 & 0.006 \\
\hline & {$[0.016]^{* * *}$} & {$[0.016]^{* * *}$} & {$[0.020]$} & {$[0.019]$} \\
\hline \multirow[t]{2}{*}{ Visa type: Independent } & -0.055 & -0.075 & -0.035 & -0.030 \\
\hline & {$[0.018]^{* * *}$} & {$[0.020]^{* * *}$} & {$[0.019]^{*}$} & {$[0.018]^{*}$} \\
\hline \multirow[t]{2}{*}{ Visa type: Humanitarian } & -0.013 & -0.011 & -0.032 & -0.034 \\
\hline & {$[0.044]$} & {$[0.049]$} & {$[0.026]$} & {$[0.025]$} \\
\hline \multirow[t]{2}{*}{ Educ. mismatch FHC: not working } & 0.009 & -0.002 & 0.287 & 0.305 \\
\hline & {$[0.026]$} & {$[0.027]$} & {$[0.046]^{* * *}$} & {$[0.048]^{* * *}$} \\
\hline \multirow[t]{2}{*}{ Educ. mismatch FHC: over-educated } & 0.453 & 0.477 & -0.077 & -0.072 \\
\hline & {$[0.048]^{* * *}$} & {$[0.046]^{* * *}$} & {$[0.020]^{* * *}$} & {$[0.020]^{* * *}$} \\
\hline \multirow[t]{2}{*}{ Educ. mismatch FHC: under-educated } & -0.138 & -0.151 & 0.617 & 0.617 \\
\hline & {$[0.016]^{* * *}$} & {$[0.017]^{* * *}$} & {$[0.030]^{* * *}$} & {$[0.031]^{* * *}$} \\
\hline \multirow[t]{2}{*}{ Cohort 2} & -0.030 & -0.039 & 0.018 & 0.018 \\
\hline & {$[0.015]^{* *}$} & {$[0.016]^{* *}$} & {$[0.015]$} & {$[0.015]$} \\
\hline Regional fixed effects & Yes & Yes & Yes & Yes \\
\hline \multicolumn{5}{|l|}{ Selection equation (Probability of being employed) } \\
\hline \multirow[t]{2}{*}{ Age } & 0.000 & 0.001 & 0.001 & 0.001 \\
\hline & {$[0.009]$} & {$[0.009]$} & {$[0.009]$} & {$[0.009]$} \\
\hline \multirow[t]{2}{*}{ Age squared $\times 100$} & -0.014 & -0.014 & -0.015 & -0.015 \\
\hline & {$[0.011]$} & {$[0.011]$} & {$[0.011]$} & {$[0.011]$} \\
\hline \multirow[t]{2}{*}{ Interview in English } & 0.065 & 0.068 & 0.071 & 0.071 \\
\hline & {$[0.025]^{* * *}$} & {$[0.025]^{* * *}$} & {$[0.025]^{* * *}$} & {$[0.025]^{* * *}$} \\
\hline Visited Australia before immigration & 0.090 & 0.083 & 0.082 & 0.082 \\
\hline
\end{tabular}


Table 5 Probit with sample selection estimates of over- and under-education (marginal effects) - Cohort 1\&2, Wave 1 (5 months after arrival) (Continued)

\begin{tabular}{|c|c|c|c|c|}
\hline & {$[0.020]^{* * *}$} & {$[0.021]^{* * *}$} & {$[0.021]^{* * *}$} & {$[0.021]^{* * *}$} \\
\hline \multirow[t]{2}{*}{ Visa type: Concessional Family/Skilled-Austr. Link } & 0.075 & 0.074 & 0.074 & 0.074 \\
\hline & {$[0.023]^{* * *}$} & {$[0.023]^{* * *}$} & {$[0.023]^{* * *}$} & {$[0.023]^{* * *}$} \\
\hline \multirow[t]{2}{*}{ Visa type: Business Skills \& Empl. Nomination Scheme } & 0.334 & 0.335 & 0.335 & 0.335 \\
\hline & {$[0.014]^{* * *}$} & {$[0.014]^{* * *}$} & {$[0.014]^{* * *}$} & {$[0.014]^{* * *}$} \\
\hline \multirow[t]{2}{*}{ Visa type: Independent } & 0.082 & 0.081 & 0.080 & 0.080 \\
\hline & {$[0.023]^{* * *}$} & {$[0.023]^{* * *}$} & {$[0.023]^{* * *}$} & {$[0.023]^{* * *}$} \\
\hline \multirow[t]{2}{*}{ Visa type: Humanitarian } & -0.305 & -0.310 & -0.312 & -0.312 \\
\hline & {$[0.041]^{* * *}$} & {$[0.041]^{* * *}$} & {$[0.041]^{* * *}$} & {$[0.041]^{* * *}$} \\
\hline \multirow[t]{2}{*}{ Number of adults in household } & -0.027 & -0.027 & -0.028 & -0.028 \\
\hline & {$[0.006]^{* * *}$} & {$[0.006]^{* * *}$} & {$[0.006]^{* * *}$} & {$[0.006]^{* * *}$} \\
\hline \multirow[t]{2}{*}{ Children present } & 0.051 & 0.055 & 0.061 & 0.060 \\
\hline & {$[0.020]^{* * *}$} & {$[0.020]^{* * *}$} & {$[0.020]^{* * *}$} & {$[0.020]^{* * *}$} \\
\hline \multirow[t]{2}{*}{ HH owns car } & 0.151 & 0.148 & 0.144 & 0.144 \\
\hline & {$[0.022]^{* * *}$} & {$[0.023]^{* * *}$} & {$[0.023]^{* * *}$} & {$[0.023]^{* * *}$} \\
\hline \multirow[t]{2}{*}{ Cohort 2} & 0.144 & 0.143 & 0.142 & 0.142 \\
\hline & {$[0.018]^{* * *}$} & {$[0.018]^{* * *}$} & {$[0.018]^{* * *}$} & {$[0.018]^{* * *}$} \\
\hline Regional fixed effects & Yes & Yes & Yes & Yes \\
\hline Observations & 3048 & 3048 & 3048 & 3048 \\
\hline Censored obs & 962 & 962 & 962 & 962 \\
\hline Wald chi2 & 282.40 & 297.03 & 656.87 & 654.29 \\
\hline Log likelihood & -2138.46 & -2120.38 & -1915.63 & -1909.17 \\
\hline \multirow[t]{2}{*}{$\rho$} & 0.803 & 0.381 & -0.105 & -0.049 \\
\hline & {$[0.312]^{* *}$} & {$[0.326]$} & {$[0.149]$} & {$[0.152]$} \\
\hline \multicolumn{5}{|l|}{ Standard errors in brackets } \\
\hline${ }^{*}$ significant at $10 \%$; ${ }^{* *}$ significant at $5 \% ;{ }^{* *}$ significant at $1 \%$ & & & & \\
\hline
\end{tabular}

Note: The base group for "Formal Home Country" (FHC) is "English speaking OECD"; for "Visa type" the base group is "Preferential Family/ Family Stream"; and for "Education mismatch FHC" the base group is "Correctly matched".

probability to be under-educated at five months after arrival by about 62 percent. The difference between the sizes of the two effects could be explained by the fact that the immigrant population is likely to be non-randomly selected from the home countries' populations. Assuming that immigrants are positively selected with respect to unobserved abilities and motivation, they would be expected to put more effort in climbing up the occupational ladder (see Chiswick 1978). Therefore, the best from the under-educated group in the home country are likely to have a higher probability to be under-educated in Australia and the best of the over-educated in the home market are likely to have a lower probability to be over-educated in Australia. The effect of that would be lower observed coefficients between over-education at origin and over-education in Australia and greater observed coefficients between under-education at origin and in Australia compared to the ones that would be obtained in the absence of selection bias. Nevertheless, we cannot correct for this due to the lack of information about the socio-economic characteristics of the home countries' populations. 
Table 6 Probit with sample selection estimates of over- and under-education (marginal effects) - Cohort 1\&2, Wave 2 (17 months after arrival)

\begin{tabular}{|c|c|c|c|c|}
\hline & $(1)$ & $(2)$ & (3) & (4) \\
\hline & \multicolumn{2}{|c|}{ Over-education } & \multicolumn{2}{|c|}{ Under-education } \\
\hline \multirow[t]{2}{*}{ Age } & -0.002 & 0.003 & 0.006 & 0.001 \\
\hline & {$[0.007]$} & {$[0.007]$} & {$[0.006]$} & {$[0.006]$} \\
\hline \multirow[t]{2}{*}{ Age squared x 100} & 0.002 & -0.004 & -0.008 & -0.003 \\
\hline & {$[0.009]$} & {$[0.009]$} & {$[0.007]$} & {$[0.008]$} \\
\hline \multirow[t]{2}{*}{ Qualification assessed } & 0.026 & 0.030 & -0.078 & -0.099 \\
\hline & {$[0.016]$} & {$[0.017]^{*}$} & {$[0.015]^{* * *}$} & {$[0.017]^{* * *}$} \\
\hline \multirow[t]{2}{*}{ Self-Employed } & -0.059 & -0.055 & 0.118 & 0.092 \\
\hline & {$[0.019]^{* * *}$} & {$[0.019]^{* * *}$} & {$[0.028]^{* * *}$} & {$[0.029]^{* * *}$} \\
\hline \multirow[t]{2}{*}{ FHC: Non-English Speaking OECD } & 0.029 & 0.017 & -0.014 & 0.021 \\
\hline & {$[0.029]$} & {$[0.028]$} & {$[0.020]$} & {$[0.028]$} \\
\hline \multirow[t]{2}{*}{ FHC: South, East, South East Asia and Oceania } & 0.085 & 0.002 & -0.060 & -0.001 \\
\hline & {$[0.023]^{* * *}$} & {$[0.021]$} & {$[0.016]^{* * *}$} & {$[0.022]$} \\
\hline \multirow[t]{2}{*}{ FHC: Sub-Saharan Africa } & -0.003 & -0.041 & 0.004 & 0.099 \\
\hline & {$[0.033]$} & {$[0.026]$} & {$[0.026]$} & {$[0.042]^{* *}$} \\
\hline \multirow[t]{2}{*}{ FHC: Other } & 0.107 & 0.021 & -0.036 & -0.010 \\
\hline & {$[0.029]^{* * *}$} & {$[0.025]$} & {$[0.019]^{*}$} & {$[0.025]$} \\
\hline \multirow[t]{2}{*}{ Visa type: Concessional Family/Skilled-Austr. Link } & -0.006 & 0.026 & 0.012 & -0.028 \\
\hline & {$[0.020]$} & {$[0.022]$} & {$[0.022]$} & {$[0.021]$} \\
\hline \multirow[t]{2}{*}{ Visa type: Business Skills \& Empl. Nomination Scheme } & -0.147 & -0.076 & 0.008 & 0.001 \\
\hline & {$[0.014]^{* * *}$} & {$[0.021]^{* * *}$} & {$[0.020]$} & {$[0.024]$} \\
\hline \multirow[t]{2}{*}{ Visa type: Independent } & -0.079 & -0.033 & -0.046 & -0.072 \\
\hline & {$[0.016]^{* * *}$} & {$[0.019]^{*}$} & {$[0.018]^{* *}$} & {$[0.019]^{* * *}$} \\
\hline \multirow[t]{2}{*}{ Visa type: Humanitarian } & -0.036 & -0.043 & -0.030 & -0.021 \\
\hline & {$[0.022]$} & {$[0.021]^{* *}$} & {$[0.021]$} & {$[0.025]$} \\
\hline \multirow[t]{2}{*}{ Educ. mismatch FHC: not working } & -0.042 & & 0.338 & \\
\hline & {$[0.019]^{* *}$} & & {$[0.045]^{* * *}$} & \\
\hline \multirow[t]{2}{*}{ Educ. mismatch FHC: over-educated } & 0.334 & & -0.073 & \\
\hline & {$[0.044]^{* * *}$} & & {$[0.021]^{* * *}$} & \\
\hline \multirow[t]{2}{*}{ Educ. mismatch FHC: under-educated } & -0.154 & & 0.565 & \\
\hline & {$[0.012]^{* * *}$} & & {$[0.027]^{* * *}$} & \\
\hline \multirow[t]{2}{*}{ Educ. mismatch Wave 1: not working } & & 0.210 & & 0.221 \\
\hline & & {$[0.023]^{* * *}$} & & {$[0.025]^{* * *}$} \\
\hline \multirow[t]{2}{*}{ Educ. mismatch Wave 1: over-educated } & & 0.657 & & -0.020 \\
\hline & & {$[0.036]^{* * *}$} & & {$[0.031]$} \\
\hline \multirow[t]{2}{*}{ Educ. mismatch Wave 1: under-educated } & & -0.071 & & 0.824 \\
\hline & & {$[0.024]^{* * *}$} & & {$[0.022]^{* * *}$} \\
\hline \multirow[t]{2}{*}{ Cohort 2} & -0.011 & 0.014 & 0.062 & 0.045 \\
\hline & {$[0.014]$} & {$[0.015]$} & {$[0.016]^{* * *}$} & {$[0.017]^{* * *}$} \\
\hline Regional fixed effects & Yes & Yes & Yes & Yes \\
\hline \multicolumn{5}{|l|}{ Selection equation (Probability of being employed) } \\
\hline Age & 0.010 & 0.011 & 0.013 & 0.012 \\
\hline
\end{tabular}


Table 6 Probit with sample selection estimates of over- and under-education (marginal effects) - Cohort 1\&2, Wave 2 (17 months after arrival) (Continued)

\begin{tabular}{|c|c|c|c|c|}
\hline & {$[0.005]^{*}$} & {$[0.005]^{* *}$} & {$[0.005]^{* *}$} & {$[0.005]^{* *}$} \\
\hline \multirow[t]{2}{*}{ Age squared x 100} & -0.019 & -0.020 & -0.022 & -0.021 \\
\hline & {$[0.007]^{* * *}$} & {$[0.007]^{* * *}$} & {$[0.007]^{* * *}$} & {$[0.007]^{* * *}$} \\
\hline \multirow[t]{2}{*}{ Interview in English } & 0.062 & 0.065 & 0.083 & 0.087 \\
\hline & {$[0.018]^{* * *}$} & {$[0.017]^{* * *}$} & {$[0.019]^{* * *}$} & {$[0.020]^{* * *}$} \\
\hline \multirow[t]{2}{*}{ Visited Australia before immigration } & 0.084 & 0.078 & 0.081 & 0.082 \\
\hline & {$[0.014]^{* * *}$} & {$[0.014]^{* * *}$} & {$[0.015]^{* * *}$} & {$[0.015]^{* * *}$} \\
\hline \multirow[t]{2}{*}{ Visa type: Concessional Family/Skilled-Austr. Link } & 0.034 & 0.030 & 0.026 & 0.026 \\
\hline & {$[0.015]^{* *}$} & {$[0.015]^{* *}$} & {$[0.016]^{*}$} & {$[0.016]^{*}$} \\
\hline \multirow[t]{2}{*}{ Visa type: Business Skills \& Empl. Nomination Scheme } & 0.139 & 0.138 & 0.137 & 0.136 \\
\hline & {$[0.011]^{* * *}$} & {$[0.011]^{* * *}$} & {$[0.011]^{* * *}$} & {$[0.011]^{* * *}$} \\
\hline \multirow[t]{2}{*}{ Visa type: Independent } & 0.049 & 0.048 & 0.044 & 0.044 \\
\hline & {$[0.015]^{* * *}$} & {$[0.015]^{* * *}$} & {$[0.015]^{* * *}$} & {$[0.015]^{* * *}$} \\
\hline \multirow[t]{2}{*}{ Visa type: Humanitarian } & -0.170 & -0.173 & -0.165 & -0.162 \\
\hline & {$[0.030]^{* * *}$} & {$[0.030]^{* * *}$} & {$[0.030]^{* * *}$} & {$[0.030]^{* * *}$} \\
\hline \multirow[t]{2}{*}{ Number of adults in household } & -0.010 & -0.008 & -0.010 & -0.011 \\
\hline & {$[0.004]^{* *}$} & {$[0.004]^{* *}$} & {$[0.005]^{* *}$} & {$[0.005]^{* *}$} \\
\hline \multirow[t]{2}{*}{ Children present } & 0.043 & 0.046 & 0.056 & 0.056 \\
\hline & {$[0.013]^{* * *}$} & {$[0.013]^{* * *}$} & {$[0.013]^{* * *}$} & {$[0.013]^{* * *}$} \\
\hline \multirow[t]{2}{*}{ HH owns car } & 0.118 & 0.117 & 0.124 & 0.122 \\
\hline & {$[0.020]^{* * *}$} & {$[0.021]^{* * *}$} & {$[0.022]^{* * *}$} & {$[0.022]^{* * *}$} \\
\hline \multirow[t]{2}{*}{ Cohort 2} & 0.067 & 0.065 & 0.060 & 0.059 \\
\hline & {$[0.012]^{* * *}$} & {$[0.012]^{* * *}$} & {$[0.012]^{* * *}$} & {$[0.012]^{* * *}$} \\
\hline Regional fixed effects & Yes & Yes & Yes & Yes \\
\hline Observations & 2918 & 2918 & 2918 & 2918 \\
\hline Censored obs & 497 & 497 & 497 & 497 \\
\hline Wald chi2 & 312.76 & 490.38 & 691.76 & 719.04 \\
\hline Log likelihood & -1907.95 & -1783.69 & -1654.33 & -1601.07 \\
\hline \multirow[t]{2}{*}{$\rho$} & 1.899 & 1.446 & -0.002 & 0.258 \\
\hline & {$[1.165]$} & {$[0.630]^{* *}$} & {$[0.174]$} & {$[0.212]$} \\
\hline Standard errors in brackets & & & & \\
\hline
\end{tabular}

Note: The base group for "Formal Home Country" (FHC) is "English speaking OECD"; for "Visa type" the base group is "Preferential Family/ Family Stream"; and for "Education mismatch FHC" the base group is "Correctly matched".

Australian employers seem to put the least value on professional experience from South, East, South East Asia and Oceania as well as from countries in Eastern Europe and Central Asia, Middle East and North Africa, and Latin America and the Caribbean. Compared to having lived and worked in Canada, Ireland, the UK or the US, immigrants from Asia (South, East and South East) and Oceania had about 13.3 percent higher probability of being over-educated at five months after arrival, whereas having migrated from Eastern Europe and Central Asia, Middle East and North Africa, or Central and South America increased the over-education probability by about 13.5 percent. 
As found also by Green et al. (2007), having entered Australia with a visa that required the proof of business or professional skills significantly decreases the likelihood of over-education: compared to a Preferential Family Visa, our reference category, having immigrated with a Business Skills Visa or through the Employer Nomination Scheme decreases the probability of being over-educated by about 16 to 17 percent, while having entered with an Independent Skilled Visa decreases it by about 5.5 to 7.5 percent.

Having an overseas qualification assessed in Australia does not seem to improve the education-occupation match, at least not in the first three years after arrival. Even after 17 months of arrival, the assessment of a foreign qualification is more common among those immigrants that fail to find a job in which they can fully use their qualifications: having the qualification assessed is positively related to working below the formal education level and negatively related to working above it.

The comparison of home country mismatch effect at 5 and 17 months after arrival (Tables 5 and 6 respectively) shows that it becomes weaker with the length of residence in Australia ${ }^{13}$. The relation of over-education in Australia to over-education in the home country decreases from about 48 percent at five months to about 33 percent at 17 months after immigration, while the effect of under-education in the home country on under-education in Australia decreases from 62 to 56 percent. This is consistent with the argument that a more recent signal about the real productivity/ability, after starting work in Australia, has a much stronger effect on over-education incidence (at 17 months after arrival; marginal effect of 0.66) compared to the signal from overeducation in the home country (marginal effect of 0.33 ). Similarly, the probability of being under-educated at 17 months after immigration is about 82 percent higher if the immigrant was under-educated at five months after landing, but only 56 percent higher if it was under-educated in the home country.

At 17 months after arrival, the probability of being employed of Cohort 2 vs. Cohort 1 immigrants drops from 14 percent to about 6 percent, depending on the type of mismatch. However, Cohort 2 immigrants become approximately 5 to 6 percent more likely to be under-educated, providing evidence of an eventual better selection with regard to unobservable skills after the 1996 reform in Australia's immigration policy.

\section{Conclusions}

The main objective of the paper was to investigate the role of a possible mismatch of an immigrant in the home country on his subsequent mismatch in the host country. Many immigrants appear to have work experience before migration in jobs below (or above) their education level, which might generate a negative (or positive) effect on their average skill level. Therefore, taking into account the level of professional experience achieved before migration, along with the formal education qualifications, provides a more accurate estimate of the immigrants' real productivity, especially since the education signal attenuates with work experience.

We used the Longitudinal Survey of Immigrants to Australia for two cohorts of immigrants who entered the country in 1993-1995 and 1999/2000 respectively and showed that the inclusion of covariates capturing the mismatch already experienced in the home country almost doubles the explanatory power of probit models 
estimating the over-education of immigrants and almost quadruples the explanatory power of the models assessing the under-education of immigrants.

After controlling for selection into employment and the effect of various socioeconomic characteristics, over- and under-education in the home country continue to have the strongest effect among all covariates: having been over-educated in the last job held in the home country increases the likelihood of over-education at five months after arrival in Australia by about 45 percent, while having been undereducated at home increases the probability of under-education in Australia by about 61 percent. The importance of "ability signals" in path dependency in over-I under-education is also confirmed by the fact that the education-occupation mismatch after 17 months of residence is significantly dependent on the educationoccupation mismatch experiences immediately after arrival in Australia.

The more stringent rules on access to social security payments faced by the second immigrant cohort increased their employment probability relative to the first cohort. However in contradiction to Green et al. (2007), we found no evidence that the constraint of finding a job sooner has resulted in a poorer matching incidence for the second cohort; this being probably the effect of the tighter selection criteria with respect to skills under the points-based system.

\section{Endnotes}

${ }^{1}$ There are a number of other authors who have shown similar results (see for instance, McGuinness 2006; Mavromara et al, 2009 and McGuinness and Sloane 2011).

${ }^{2}$ See McGuiness (2003) and McGuiness and Wooden (2009).

3 See for instance, McGuinness and Sloane (2011), Chevalier and Lindley (2009), McGuinness (2006), Voon and Miller (2005), Battu and Sloane (2004), Gottschalk and Hansen (2003), Bauer (2002), Dolton and Vignoles (2000), Hartog (2000) and McGoldrick and Robst (1996).

${ }^{4}$ Recent work suggests that more than 50 percent of a country's employed are not correctly matched (see Leuven and Oostorbeek 2011).

${ }^{5}$ It has become a stylised fact now that over-educated employees earn less than those with the required education level. This conclusion of course rests on the assumption that the returns to human capital are mostly affected by formal education rather than training and learning on the job (e.g., Ben-Porath 1967; Heckman 1976; and Mincer 1997) or career interruptions or switches (e.g., Mincer and Ofek 1982).

${ }^{6}$ See a recent survey of literature on migrants' overeducation by Piracha and Vadean (2012).

${ }^{7}$ Possible discrimination against immigrants in the US is also suggested by Chiswick and Miller (2010).

${ }^{8}$ See http://www.immi.gov.au/employers/_pdf/ansco-anzsco-differences.pdf.

${ }^{9}$ Migrants interviewed in LSIA 1 will be referred to as Cohort 1 and those in LSIA 2 will be referred to as Cohort 2 in the rest of the paper.

${ }^{10}$ Migrating unit is this context includes all members of the family migrating to Australia under the same visa application. The term spouse is used for husband/ wife, civil partners, fiancé(e)s and de facto partners. 
${ }^{11}$ There are five visa categories used to enter Australia: Independent skills, Business/ Employer Nominated, Preferential Family, Concessional Family and Refugee. See Green et al. (2007) for a discussion.

${ }^{12}$ Due to the very small sub-samples of immigrants in the Australian Capital Territory (ACT), Tasmania and Northern Australia, we merged these with New South Wales, South Australia and Western Australia respectively. The pairing was made on the basis of geographical proximity as well as labour market similarities in terms of average unemployment rates and average weekly earnings of employees. Hence, our five regional dummies are: 'New South Wales \& ACT,' 'Victoria,' 'Queensland,'South Australia \& Tasmania,' and 'Northern \& Western Australia'.

${ }^{13}$ Only immigrants of Cohort 1 were interviewed also at 41 months after arrival, the longest period in the data. However, the maximum likelihood estimations of the probit model with sample selection failed to reach a maximum for most settings using Cohort 1 separately, due to the limited number of observations in certain sub-categories. In settings for which the estimations reached a maximum, we encountered the problem of very high standard errors. We therefore do not present here the results, but they are available from the authors upon request.

\section{Competing interests}

The IZA Journal of Migration is committed to the IZA Guiding Principles of Research Integrity. The authors declare that they have observed these principles.

\section{Acknowledgments}

We would like to thank Corrado Giulietti, seminar participants at the University of Sussex, the $8^{\text {th }}$ IZA Annual Migration Meeting, Washington D.C. and three referees for helpful comments. Part of the paper was completed during Matloob Piracha's visit to the Macquarie University's Faculty of Business and Economics. He is grateful for their hospitality and financial support. Florin Vadean gratefully acknowledges financial support from the European Commission through the Research Training Network "Transnationality of Migrants" (6 ${ }^{\text {th }}$ Framework Programme). The usual disclaimer applies.

Responsible Editor: Corrado Giulietti

\section{Author details}

${ }^{1}$ School of Economics, University of Kent, Canterbury, Kent CT2 7NP, UK and IZA, Bonn, Germany. ${ }^{2}$ Faculty of Business and Economics, Macquarie University, Sydney, Kent NSW 2109, Australia and IZA, Bonn, Germany. ${ }^{3}$ School of Economics, University of Kent, Canterbury, Kent CT2 7NP, UK.

Received: 23 March 2012 Accepted: 20 June 2012

Published: 9 October 2012

\section{References}

Battu H, Sloane PJ (2004) Over-education and ethnic minorities in Britain. Manch Sch 72(4):535-559

Bauer T (2002) Educational mismatch and wages: A panel analysis. Econ Educ Rev 21:221-229

Belman D, Heywood JS (1997) Sheep skin effects by cohort: Implications of job matching in a signaling Model. Oxf Econ Pap 49:623-637

Ben-Porath Y (1967) The production of human capital and the life cycle of earnings. J Polit Econ 75(4, Part 1):352-365

Boyes W, Hoffman D, Low S (1989) An econometric analysis of the bank credit scoring problem. J Econ 40:3-14

Chevalier A, Lindley J (2009) Overeducation and the skills of UK graduates. J R Stat Soc, Series A 172(2):307-338

Chiswick BR (1978) The effect of Americanization on the earnings of foreign-born men. J Polit Econ 86(5):897-921

Chiswick BR, Miller PW (2004) Language Skills and Immigrant Adjustment: What Immigration Policy Can Do! In: CobbClark D, Khoo S-E(eds.), Public Policy and Immigrant Settlement, Cheltenham: Edward Elgar 121-148.

Chiswick BR, Miller PW (2009) The international transferability of immigrants' human capital skills. Econ Educ Rev 28 (2):162-169

Chiswick BR, Miller PW (2010) Education mismatch: Are high-skilled immigrants really working at high-skilled jobs and the price they pay if they aren't? In: Chiswick BR (ed) High Skilled Immigration in a Global Labor Market. American Enterprise Institute Press, Washington DC, pp 111-154

Cobb-Clark D (2003) Public policy and the labor market adjustment of new immigrants to Australia. J Popul Econ 16 (4):655-681

Cutillo A, Di Pietro G (2006) The effects of overeducation on wages in Italy: A bivariate selectivity approach. Int J Manpow 27(2):143-168

Dolton PJ, Vignoles A (2000) The incidence and effects of overeducation in the UK graduate labour market. Econ Educ Rev 19(2):179-198 
Gottschalk P, Hansen M (2003) Is the proportion of college workers in non-college jobs increasing? J Labor Econ 21 (2):449-471

Green C, Kler P, Leeves G (2007) Immigrant overeducation: Evidence from recent arrivals to Australia. Econ Educ Rev 26 (4): $420-432$

Groot W, Maassen van den Brink H (2000) Overeducation in the labor market: A meta-analysis. Econ Educ Rev 19 (2):149-158

Hartog J (2000) Over-education and earnings: Where are we, where should we go? Econ Educ Rev 19(2):131-147 Heckman JJ (1976) A life-cycle model of earnings, learning, and consumption. J Polit Econ 84(4, Part 2):S11-S44 Junankar PN, Mahuteau S (2005) Do migrants get good jobs? New migrant settlement in Australia. Econ Rec 81 (Supplement 1):S34-S46

Lahiri K, Song JG (2000) The effect of smoking on health using a sequential self-selection model. Health Econ 9(6):491-511

Leuven E, Oostorbeek H (2011) Overeducation and mismatch in the labor market, IZA Discussion Paper No. 5523., IZA, Bonn

Litchfield J, Reilly B (2009) Modeling migration attempts and the role of gender in Albania. Economic Annals 52(182):7-39 Lundberg S, Rose E (2002) The effects of sons and daughters on men's labor supply and wages. Rev Econ Stat 84(2):251-268

Mavromara K, McGuiness S, Yin Fok K (2009) Assessing the incidence and wage effects of overskilling in the Australian labour market, Economic Record 85(268):60-72.

McGoldrick K, Robst J (1996) Gender differences in overeducation: A test of the theory of differential overqualification. Am Econ Rev 86(2):280-284

McGuiness S (2003) Overeducation as a sheepskin effect: evidence from Northern Ireland. Appl Econ 35(5):597-608

McGuinness S (2006) Overeducation in the labour market. J Econ Surv 20(3):387-418

McGuinness S, Sloane PJ (2011) Labour market mismatch among UK graduates: An analysis using Reflex data. Econ Educ Rev 30(1):130-145

McGuiness S, Wooden M (2009) Overskilling, job insecurity and career mobility Industrial Relations. A J Economy and Soc 48(2):265-286

Mincer J (1997) The production of human capital and the life cycle of earnings: Variations on a theme. J Labor Econ 15 (1, Part 2):S26-S47

Mincer J, Ofek H (1982) Interrupted work careers: Depreciation and restoration of human capital. J Hum Resour 17(1):3-24

Murray M (2006) Avoiding invalid instruments and coping with weak instruments. J Econ Perspect 20(4):111-132

Piracha M, Vadean F (2012) Migrant educational mismatch and the labour market. In: Constant A, Zimmermann K (eds) International Handbook on the Economics of Migration. Edward Elgar, Cheltenham, UK

Raphael S, Stoll M (2000) Can boosting minority car-ownership rates narrow inter-racial employment gaps? Working Paper W00-002, Berkeley Program on Housing and Urban Policy. Berkeley, USA

Rumberger RW (1987) The Impact of Surplus Schooling on Productivity and Earnings. J Hum Resour 22(1):24-50 Sicherman N (1991) "Overeducation" in the labor market. J Labour Econ 9(2):101-122

Thapa PJ, Gorgens T (2006) Finding employment after migration: How long does it take? In: Cobb-Clark D, Khoo SE (eds) Public Policy and Immigrant Settlement. UK, Edgar Elgar, pp 53-86

Van De Ven PMM, Van Praag MS (1981) The demand for deductibles in private health insurance: A probit model with sample selection. J Econ 17(2):229-252

Verdugo R, Verdugo N (1989) The impact of surplus schooling on earnings: Some additional findings. Econ Educ Rev 22(4):690-695

Voon D, Miller PW (2005) Undereducation and overeducation in the Australian labour market. Econ Rec 81 (Supplement 1): S22-\$33

doi:10.1186/2193-9039-1-3

Cite this article as: Piracha et al: Immigrant over- and under-education: the role

of home country labour market experience. IZA Journal of Migration 2012 1:3.

\section{Submit your manuscript to a SpringerOpen ${ }^{\circ}$} journal and benefit from:

- Convenient online submission

- Rigorous peer review

- Immediate publication on acceptance

- Open access: articles freely available online

- High visibility within the field

- Retaining the copyright to your article

Submit your next manuscript at $>$ springeropen.com 